\title{
Administration of BAY 41-2272 prevents bladder dysfunction in nitric-oxide deficient rats
}

\author{
Administração de BAY 41-2272 previne disfunção vesical em ratos deficientes de oxido nítrico \\ Carlos Arturo Levi D’Ancona ${ }^{1}$, Fabíola Zakia Taufic Mónica ${ }^{2}$, Ricardo Reges ${ }^{3}$, David Cohen ${ }^{4}$, Fabio Henrique da Silva ${ }^{5}$, \\ Gilberto De Nucci ${ }^{6}$, Edson Antunes ${ }^{7}$
}

\begin{abstract}
Objective: to evaluate the protective effects of BAY 41-2272, a soluble guanylate cyclase activator, on changes in cystometric parameters in rats deficient in nitric oxide (NO). Methods: Rats were divided into the following groups: (a) control; (b) DMSO; (c) L-NAME; (d) BAY 41-2272 alone; (e) L-NAME + BAY 41-2272. The NO synthase blocker L-NAME (20 mg/rat/day) was given in drinking water concomitantly or not with BAY $41-2272(10 \mathrm{mg} /$ $\mathrm{kg} /$ day, given by gavage). Results: Chronic L-NAME treatment markedly increased the mean arterial blood pressure, and cotreatment with BAY 41-2272 nearly reversed L-NAME-induced rise on mean arterial blood pressure. Non-void contractions were significantly increased in L-NAME group $(0.90 \pm 0.1$ number/ minute) compared with either DMSO or control group $(0.49 \pm 0.1$ number/minute), which were prevented by co-treatment with BAY 41-2272 (0.56 \pm 025 number/minute; $p<0.05)$. The threshold and peak pressure increased by 70 and $44 \%$, respectively, after chronic L-NAME treatment, while co-treatment with BAY 41-2272 largely attenuated both effects ( 27 and $22 \%$ increase, respectively). The frequency of micturition cycles decreased by about of $50 \%$ in L-NAME-treated rats compared with control animals, and co-treatment with BAY 41-2272 normalized this parameter. Conclusions: Our data show that long-term oral administration of BAY 41-2272 counteracts the bladder dysfunction seen in NO-deficient rats, indicating that restoration of the NO-cGMP pathway by this compound may be of beneficial value to treat bladder symptoms.
\end{abstract}

Keywords: Guanylate cyclase; Nitric oxide; Urinary bladder, overactive; Rats

\section{RESUMO}

Objetivo: avaliar os efeitos protetores do BAY 41-2272, um ativador solúvel da guanilato ciclase, sobre alteração dos parâmetros citométricos em ratos deficientes de óxido nítrico (NO). Métodos: os ratos foram divididos nos seguintes grupos: (a) controle; (b) DMSO (c) L-NAME; (d) BAY 41-2272 isolado; (e) L-NAME + BAY 41-2272. 0 bloqueador da NO-sintase L-NAME (20 mg/rato/dia) foi ministrado na água de beber, concomitantemente ou não com o BAY 41-2272 (10 mg/kg/dia, ministrado por gavagem). Resultados: 0 tratamento crônico com L-NAME aumentou de forma acentuada a pressão arterial média, e o co-tratamento com BAY 41-2272 quase reverteu o aumento na pressão arterial média induzido por L-NAME. Contrações não esvaziadoras da bexiga mostraram-se significativamente aumentadas no grupo L-NAME $(0,90 \pm 0,1$ número/minuto) comparadas com DMSO ou grupo controle $(0,49 \pm 0,1$ número/minuto), que foram evitadas pelo co-tratamento com BAY 41-2272 (0,56 \pm 0,25 número/ minuto; $p<0,05)$. 0 limiar e o pico de pressão aumentaram em 70 e $44 \%$, respectivamente, após o tratamento crônico com L-NAME, enquanto o co-tratamento com BAY 41-2272 atenuou muito ambos os efeitos ( 27 e $22 \%$ de aumento, respectivamente). A frequência de ciclos de micção diminuiu em $50 \%$ nos ratos tratados com L-NAME em comparação aos animais controle; o cotratamento com BAY 41-2272 normalizou esse parâmetro. Conclusões: nossos dados mostram que a administração oral a longo prazo de BAY 41-2272 contrapõe-se à disfunção de bexiga vista em ratos deficientes de NO, o que sugere que a restauração da via da NO-cGMP por esse composto pode ter valor benéfico para tratar sintomas vesicais.

Descritores: Guanilato ciclase; Óxido nítrico; Bexiga urinária hiperativa; Ratos

\footnotetext{
Study carried out at the Department of Pharmacology and at the Discipline of Urology of the Universidade Estadual de Campinas - Campinas (SP), Brazil.

' Full professor at Universidade Estadual de Campinas - UNICAMP, Campinas (SP), Brazil.

${ }^{2} \mathrm{PhD}$ at Universidade Estadual de Campinas - UNICAMP, Campinas (SP), Brazil.

${ }^{3} \mathrm{PhD}$ at Universidade Estadual de Campinas - UNICAMP, Campinas (SP), Brazil.

${ }^{4}$ MD, Urologist, Universidade Estadual de Campinas - UNICAMP, Campinas (SP), Brazil.

${ }^{5}$ Master's degree at Universidade Estadual de Campinas - UNICAMP, Campinas (SP), Brazil.

${ }^{6}$ Full professor at Universidade Estadual de Campinas - UNICAMP, Campinas (SP), Brazil.

7 Post-doctorate degree; Lecturer at Universidade Estadual de Campinas - UNICAMP, Campinas (SP), Brazil.

Corresponding author: Carlos Arturo Levi D’Ancona - Rua Dr. Miguel Penteado, 1.073 - Jardim Chapadão - CEP: 13070118 - Campinas (SP), Brasil - Tel.: 19 3242-2488 - E-mail: cdancona@uol.com.br

Received: March 26, 2010 - Accepted: Oct 11, 2010
} 


\section{INTRODUCTION}

The neural pathways controlling lower urinary tract function are organized as simple on-off switching circuits that maintain a reciprocal relation between urinary bladder and urethral outlet. Intravesical pressure measurements during bladder filling in both humans and animals revealed low and relatively constant bladder pressures when bladder volume was below the threshold for inducing voiding. During bladder filling, the activity of the urethral sphincter increases thus enhancing the outlet resistance that contributes to the maintenance of urinary continence ${ }^{(1)}$.

The nitric oxide (NO)-cyclic GMP signaling pathway plays a crucial role in regulation of a variety of pathophysiological processes in mammals. In the lower urinary tract, NO synthase activity has been detected in the urothelium, smooth muscle, striated muscle, nerves and blood vessels ${ }^{(2,3)}$. Activation of the NO-cGMP signaling pathway generally results in inhibitory responses at the level of urethra and urethral sphincter, as well as of detrusor smooth muscle (DSM $)^{(4-6)}$. Evidence suggests that impairment of the NO-cGMP signaling pathway contributes to bladder overactivity ${ }^{(1)}$. Hypertrophic dilated bladders and dysfunctional urinary outlets were found in mice with targeted deletion of the gene for neuronal NO synthase $^{(7)}$. Gene deletion for cGMP-dependent protein kinase I (cGKI) also showed a micturition pattern that was irregular and characterized by frequent voidings and non-voiding bladder contractions, as well as by shorter intercontraction intervals ${ }^{(8)}$. Recently, we showed that four-week treatment with the NO synthase blocker L-NAME caused in vitro DSM hypersensitivity to muscarinic agonists via increases in the levels of $\left[{ }^{3} \mathrm{H}\right]-$ inositol-phosphate, accompanied by reductions of $\beta_{3}$ adrenoceptor-mediated DSM relaxations ${ }^{(9)}$.

The soluble guanylyl cyclase (sGC) is a widely distributed signal transduction enzyme that, under activation by nitric oxide (NO), converts GTP into the second messenger cGMP, which exerts its effect by activating cGMP-dependent protein kinases I and II, cGMP-gated ion channels and/or cGMP-regulated phosphodiesterases. NO-independent sGC activators have emerged as valuable tools to elucidate the physiopathology of the NO-sGC-cGMP signaling pathway. BAY 41-2272, known as a potent NOindependent $\mathrm{sGC}$ stimulator ${ }^{(10)}$, relaxes a number of vascular smooth muscle tissues in vitro ${ }^{(11-13)}$. This compound also prevents the arterial hypertension in spontaneously hypertensive rats ${ }^{(10)}$, as well as the myocardial infarction and cardiomyocyte hypertrophy in rats under chronic NO blockade ${ }^{(14)}$. In pig and rabbit urethral preparations in vitro, the compound $\mathrm{YC}-1$ (reported as a potent non-NO-based sGC stimulator) and BAY 41-2272 cause concentration-dependent relaxations $^{(15,16)}$. Recently, BAY 41-2272 was shown to potently relax DSM in vitro due to cGMP accumulation, and an additional mechanism involving $\mathrm{Ca}^{2+}$ influx blockade independently of cGMP production was also reported ${ }^{(17)}$. However, there is no study to investigate the potential beneficial effects of BAY 41-2272 in conditions of bladder dysfunction. Therefore, in the present study, we designed experiments to firstly evaluate the effects of chronic treatment with the NO synthase blocker, L-NAME, on cystometric parameters, and secondly the beneficial effects of long-term oral treatment with BAY 41-2272 in the bladder dysfunction of chronically NO-deficient rats.

\section{METHODS}

\section{Animals}

The experimental protocols were approved by the Ethical Principles in Animal Research adopted by the Brazilian College for Animal Experimentation (COBEA - Colégio Brasileiro de Experimentação Animal). Male Wistar rats (220 - 310 g) were used. Body weight and systolic blood pressure were evaluated weekly during four weeks by using modified tail cuff method in conscious animals.

\section{Experimental groups}

Animals were divided into four experimental groups $(\mathrm{n}=5$ each $)$, as follows:

(1) Control: rats that received tap water alone for four weeks;

(2) $80 \%$ DMSO: rats that received daily oral gavage with $80 \%$ dimethyl sulphoxide (DMSO) for four weeks;

(3) L-NAME: rats that received L-NAME (20 $\mathrm{mg} / \mathrm{rat} /$ day, given in the drinking water plus daily oral gavage of $80 \%$ DMSO for four weeks);

(4) L-NAME + BAY 41-2272: rats that received concomitantly L-NAME $(20 \mathrm{mg} / \mathrm{rat} / \mathrm{day}$, given in the drinking water) and BAY 41-2272 (10 mg/kg/day dissolved in $80 \%$ DMSO, given by daily oral gavage) for 4 weeks;

(5) BAY 41-2272: rats that received BAY 41-2271 alone $(10 \mathrm{mg} / \mathrm{kg} /$ day dissolved in $80 \%$ DMSO, given by daily oral gavage) for four weeks.

The volume of water drunk by each rat was approximately $50 \mathrm{ml} / \mathrm{rat} /$ day. Doses of L-NAME and BAY 41-2272 were chosen according to our previous studies $^{(14,18)}$. 


\section{Cystometry in anaesthetized rats}

Rats were anaesthetized with an intraperitoneal injection of urethane $(1.2 \mathrm{~g} / \mathrm{kg})$, and the carotid artery was cannulated for mean arterial blood pressure monitoring. A 1-cm incision was made along the midline of the rat abdomen. The bladder was exposed and a butterfly needle $(19 \mathrm{G})$ was inserted into the bladder dome and connected to a pressure transducer and to an infusion pump. Before starting cystometry, the bladder was emptied. Continuous cystometry (CMGs) was carried out by infusing saline into the rat bladder at a rate of $4 \mathrm{ml} / \mathrm{hr}$. The following parameters were assessed: threshold pressure (TP) at which micturition began; peak pressure (PP) during micturition; volume threshold (VT) that was calculated by the time needed for the first micturition $\mathrm{x} 4(\mathrm{ml}) / 60$ minutes; frequency of micturition calculated as cycles per minute $(\mathrm{FM})$; basal vesical pressure (BP); compliance ( $\Delta$ Volume/ $\Delta$ Pressure) and number of non-voiding contraction (NVCs). NVCs were considered as spontaneous bladder contractions greater than $4 \mathrm{mmHg}$ from the baseline pressure that did not result in voiding.

\section{Statistical analysis}

Data are expressed as mean \pm standard error of the mean (SEM) of $n$ experiments. The Instat program (GraphPad Software, Inc.) was used for statistical analysis. Statistical significance of the differences was studied by analysis of variance (ANOVA) and subsequently the Bonferroni method was applied. The level of $\mathrm{P}<0.05$ was accepted as significant.

\section{Drugs}

L-NAME (N-Nitro-L-arginine methyl ester), urethane and dimethylsulphoxide were obtained from Sigma Chemicals Co. (St. Louis, MO, USA). The compound BAY 41-2272 (5-cyclopropyl-2-[1-(2-fluoro-benzyl)1H-pyrazolo[3,4-b]pyridin-3-yl]-pyrimidin-4-ylamine) was provided by Pharma Research Center, Bayer AG (Wuppertal, Germany).

\section{RESULTS}

\section{Mean arterial blood pressure and body weight}

Figure 1 shows that four-week treatment with L-NAME elevated by $75 \%$ the mean arterial blood pressure (MABP) compared with the control group. Cotreatment with BAY 41-2272 prevented the L-NAMEinduced hypertension $(\mathrm{p}<0.001)$. Animals receiving BAY 41-2271 alone did not show any difference in the

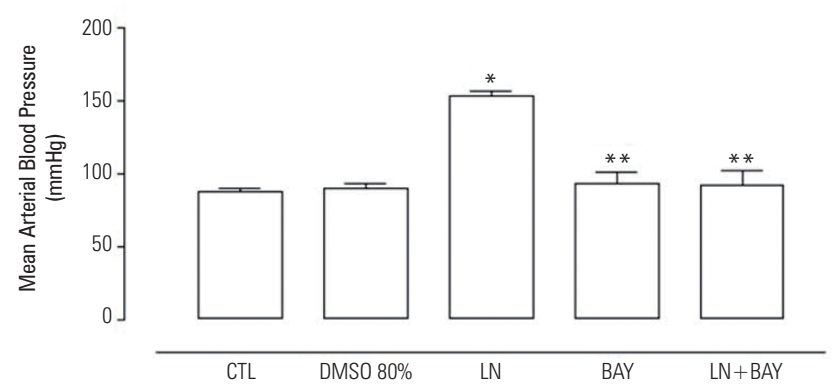

Figure 1. Effect of BAY 41-2272 (10 mg/kg/day) on mean arterial hypertension induced by chronic $\mathrm{N}$-nitro-L-arginine methyl ester (L-NAME; $20 \mathrm{mg} / \mathrm{rat} /$ day) administration in rats. Mean arterial blood pressure was measured at the end of the $4^{\text {th }}$ week in Control, $80 \%$ DMSO, L-NAME (LN), BAY and LN+BAY groups. Results are expressed as mean \pm SEM $(n=5)$. ${ }^{*} P<0.001$ compared with control group, ${ }^{* *} p<0.001$ compared with L-NAME (LN) group.

MABP compared with the control group. There were no differences in body weight between any experimental group $(318 \pm 10 ; 313 \pm 5 ; 312 \pm 6 ; 314 \pm 18$ and $310 \pm 5 \mathrm{~g}$ for control, DMSO, L-NAME, BAY 41-2272 and LN+ BAY 41-2272 groups, respectively).

\section{Bladder cystometry}

Long term L-NAME treatment caused a significant increase in the number of NVCs when compared with either control or DMSO groups ( $\mathrm{p}<0.001)$. Cotreatment with BAY 41-2272 nearly normalized these spontaneous bladder contractions during the filling phase when compared with the L-NAME group ( $\mathrm{p}<$ 0.05; Figure 2A). The VT was also significantly elevated in L-NAME-treated rats $(\mathrm{p}<0.001)$, and the cotreatment with BAY 41-2272 did not significantly affect this parameter (Figure 2B).

The BP did not significantly change among groups (Figure 3A). However, the TP and PP increased by 69 and 44\%, respectively, after chronic L-NAME treatment $(\mathrm{p}<0.001)$ when compared with control or DMSO groups (Figures 3B and 3C). Co-treatment with BAY 41-2272 nearly normalized $(\mathrm{p}<0.001)$ the elevated TP and PP seen in the L-NAME group. Figure 4 shows typical traces of spontaneous contractions during the filling phase of the micturition cycles, indicating the PP during micturition in all experimental groups.

The micturition frequency significantly decreased in L-NAME-treated rats when compared with control or DMSO groups ( $\mathrm{p}<0.001$; Figure 5A). Co-administration with BAY 41-2272 prevented the decrease in micturition frequency seen in L-NAME (LN) group. Compliance was not altered in any experimental group (Figure 5B). 

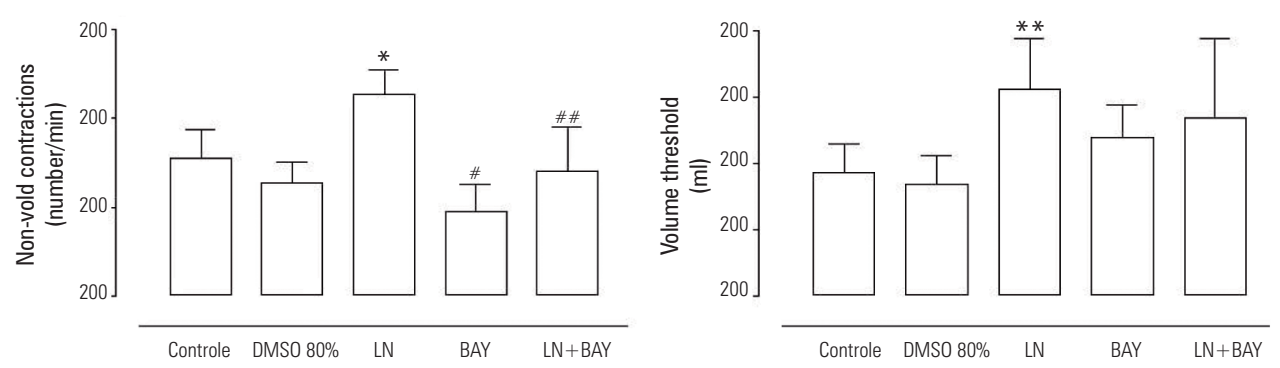

Figure 2. Changes in the non-void contractions (A) and volume threshold $(B)$ after long-term treatment with BAY $41-2242(10 \mathrm{mg} / \mathrm{kg} / \mathrm{day})$ in rats chronically treated with $\mathrm{N}$-nitro-L-arginine methyl ester (L-NAME; $20 \mathrm{mg} / \mathrm{rat} / \mathrm{day})$. Results are expressed as mean $\pm \mathrm{SEM}(\mathrm{n}=5)$. ${ }^{*} \mathrm{P}<0.01$, **p $<0.001$ compared with control group, \#p $<0.001$, \#\#p < 0.05 compared with L-NAME (LN) group.
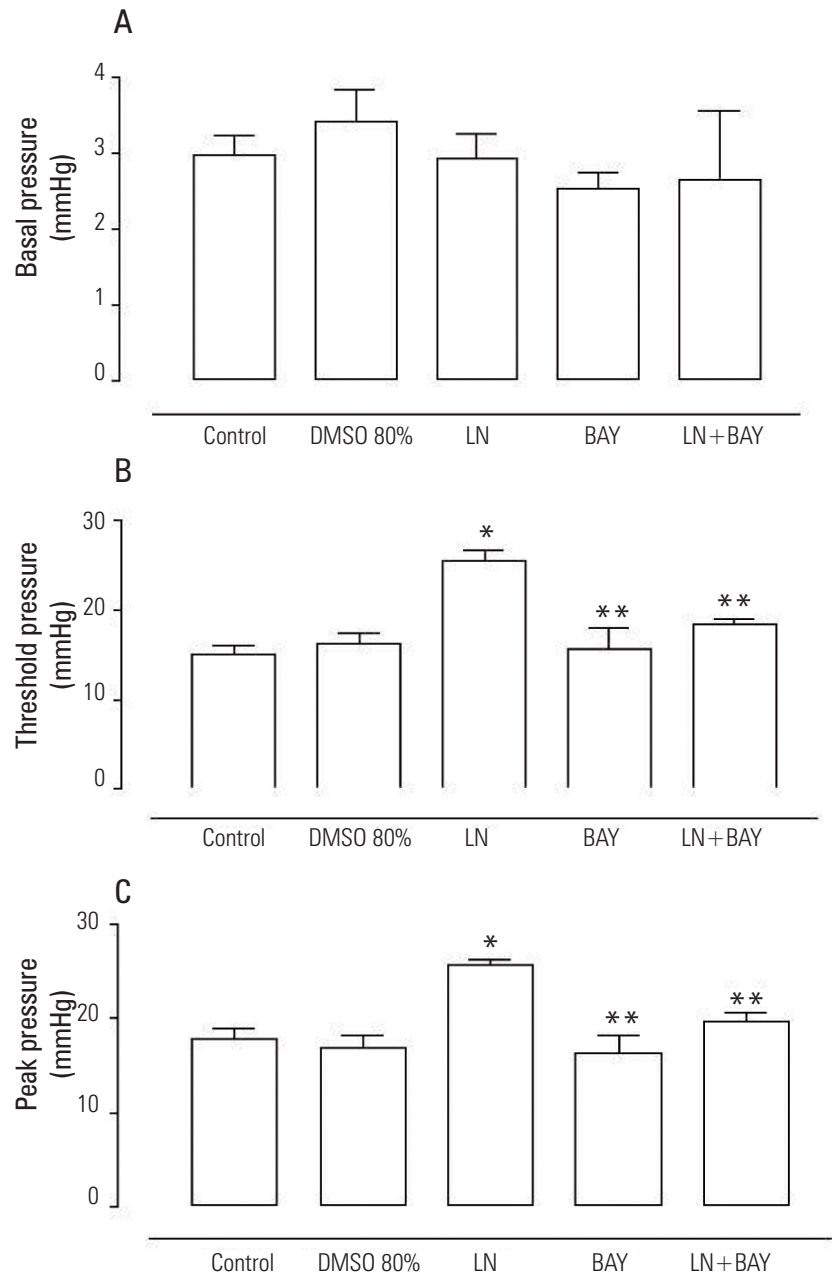

Figure 3. Changes in basal $(A)$, threshold $(B)$ and peak pressure $(C)$ after long-term treatment with BAY 41-2242 $(10 \mathrm{mg} / \mathrm{kg} /$ day) in rats treated chronically with L-NAME $\left(\mathrm{LN} ; 20 \mathrm{mg} / \mathrm{rat} /\right.$ day). Results are expressed as mean $\pm \mathrm{SEM}(\mathrm{n}=5)$. ${ }^{*} \mathrm{P}<0.001$ compared with control group, ${ }^{* *} p<0.001$ compared with L-NAME (LN) group.

\section{DISCUSSION}

The present study is the first to show that chronic NO blockade causes significant increases in NVCs, TP and $\mathrm{PP}$ along with reductions in the micturition frequency. Co-treatment with BAY 41-2272 restored all these cystometric parameters to baseline.
Pathological alterations caused by chronic NO deficiency are well documented in cardiovascular diseases. However, there are no studies evaluating the effect of chronic NO deficiency in the lower urinary tract. Indeed, most of the functional studies have reported the use of NO synthase inhibitors acutely given to whole animals ${ }^{(5)}$, or added in vitro to organ bath preparations (electrically-stimulated DSM) ${ }^{(19-20)}$. In the present study, in rats undergoing continuous cystometry, we showed that chronic L-NAME treatment significantly increased the NVCs, VT, TP and PP. Chronic L-NAME treatment also decreased the micturition frequency in comparison with control animals. Our findings are consistent with a previous study showing that acute NO inhibition completely eliminated the urethral relaxation reflex during micturition in rats, and such effect was reversed by the administration of NO synthesis substrate L-arginine ${ }^{(5)}$. Acute neuronal nitric oxide synthase (nNOS) inhibition in ovariectomized rats also significantly decreased the frequency of micturition, which paralleled an increase in residual volume ${ }^{(21)}$. A more recent study showed that mutant Immp2l male mice (animals that present low NO bioavailability due to high reactive-oxygen species generation) exhibit lower micturition volume and higher post-void volume than wild-type mice ${ }^{(22)}$. Morphometric studies showed that four-week L-NAME treatment caused increased the thickness of trigone smooth muscle without affecting DSM thickness ${ }^{(9)}$. The density of NO synthase immunoreactive nerves is also more prominent in the trigone smooth muscle and urethra than in $\operatorname{DSM}^{(23)}$. Therefore, it is likely that the lack of NO, mainly at the level of the urethra, result in a state of intense contraction thus lowering the release of urine.

The benefits of long-term treatment with BAY 41-2272 have been previously reported in the cardiovascular system in which BAY 41-2272 prevented the rise in blood pressure, myocardial infarction and cardiovascular hypertrophy in a low-NO hypertension 

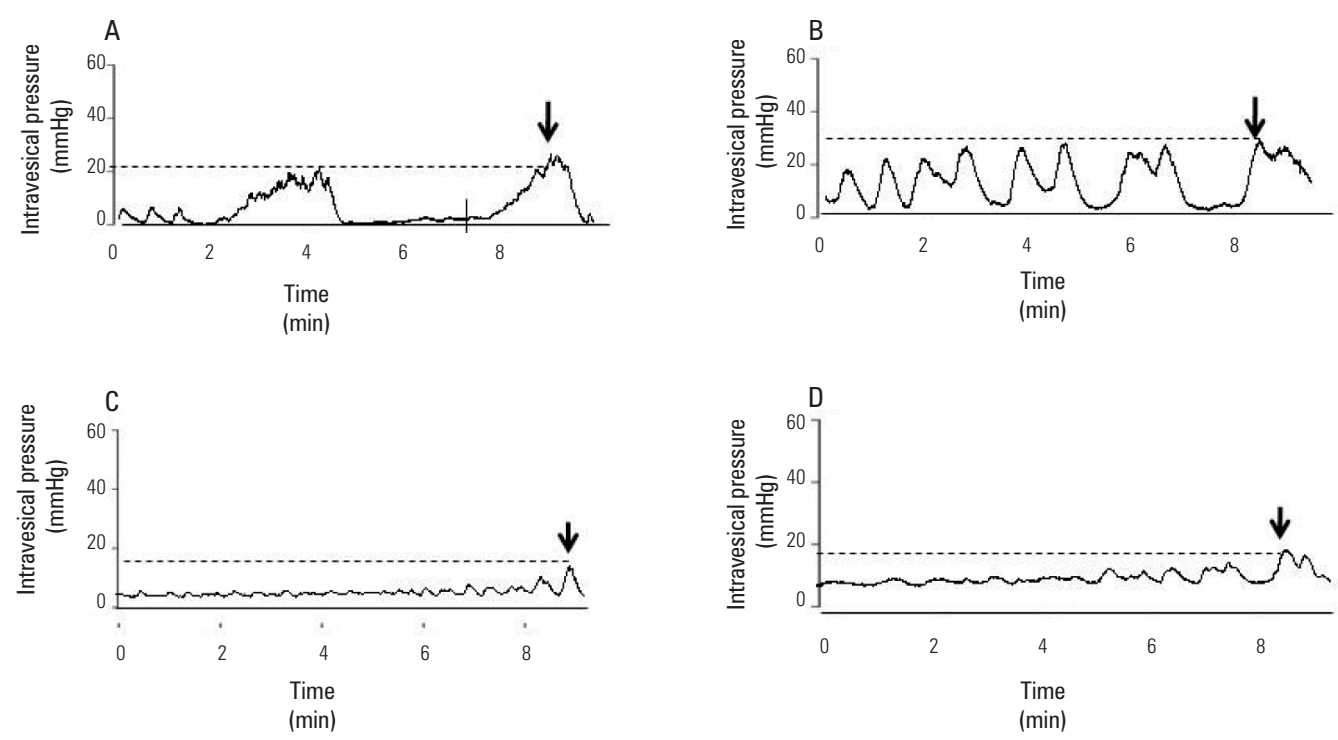

Figure 4. Representative traces showing spontaneous contractions and peak pressure (arrow) during the filling phase for (A) DMSO, (B) L-NAME (LN; 20 mg/rat/day), (C) BAY 41-2272 (10 mg/kg/day) and (D) LN + BAY 41-2272 groups.
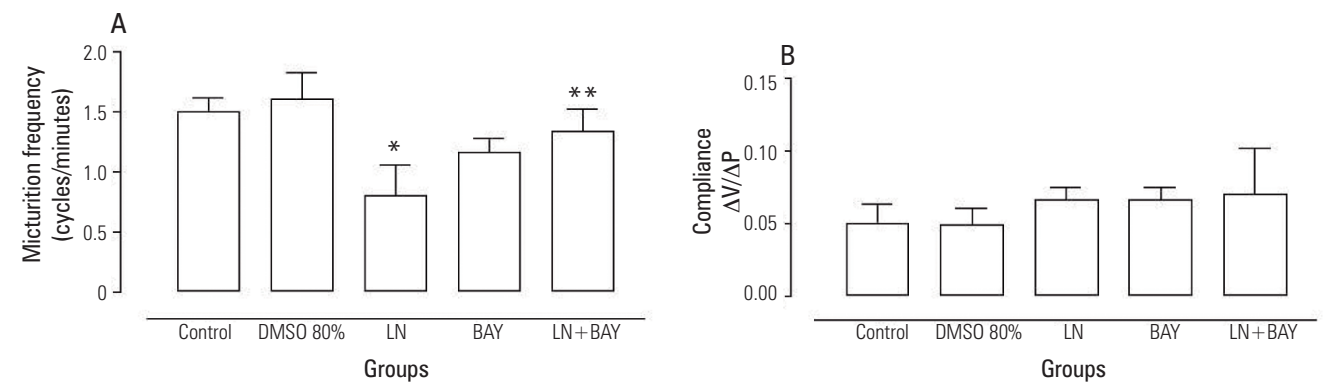

Figure 5. Changes in micturition frequency (A) and compliance (B) after long-term treatment with BAY 41-2242 (10 mg/kg/day) in rats treated chronically with L-NAME $\left(\mathrm{LN} ; 20 \mathrm{mg} / \mathrm{rat} /\right.$ day). Results are expressed as mean $\pm \mathrm{SEM}(\mathrm{n}=5)$. ${ }^{*} \mathrm{P}<0.001$ compared with control group, ${ }^{* *} \mathrm{p}<0.01$ compared with L-NAME (LN) groups.

model in rats ${ }^{(14)}$. Previous works in our laboratory also showed that BAY 41-2272 relaxed isolated urethra in a concentration-dependent manner, synergistically with the phosphodiesterase-5 inhibitor, the sildenafil ${ }^{(16)}$. In the present study, co-treatment with BAY 412272 significantly attenuated increased NVCs, TP and PP, as well as decreased micturition frequency seen in L-NAME-treated rats, indicating that direct stimulation of sGC in a NO-independent manner by BAY 41-2272 counteracts the bladder dysfunction in NO-deficient rats. In previous studies, activation of NO-cGMP signaling pathway with the NO donor, DEANO, and the membrane-permeant analogue of cGMP, 8-Br-cGMP, attenuated the spontaneous electrical activity in freshly dispersed interstitial cells of Cajal, mainly by reducing the $\mathrm{Ca}^{+2}$ waves ${ }^{(24)}$. More recently, the NO donor, SNAP, was shown to decrease the amplitude and frequency of spontaneous contractions in neonatal hyperactive rat bladder strips in a cGMP- dependent manner ${ }^{(25)}$. It is likely, therefore, that cGMP accumulation by BAY 41-2272 lead to relaxation in the urethral portion, facilitating the release of urine. The administration of $\mathrm{NO}$ donors in patients with detrusor sphincter dyssynergia or in healthy men promoted reductions in bladder outlet resistance in pressure-flow studies $^{(26,27)}$. In rats, intravesically applied S-nitroso-Nacetylpenicillamine (NO donor compound) decreased bladder overactivity induced by the chemical irritant cyclophosphamide ${ }^{(28)}$.

\section{CONCLUSIONS}

Long-term treatment with the NO-independent sGC activator, BAY 41-2272, restores the increased NVCs and intravesical pressures seen in chronic NO-deficient rats. Therefore, direct $\mathrm{sGC}$ activators, such as BAY 41-2272, could bring beneficial effects to treat bladder dysfunction symptoms. 


\section{ACKNOWLEDGEMENTS}

Fabíola Z. T. Mónica is grateful to the Fundação de Amparo à Pesquisa do Estado de São Paulo (FAPESP).

\section{REFERENCES}

1. Andersson $\mathrm{KE}$, Arner A. Urinary bladder contraction and relaxation: physiology and pathophysiology. Physiol Rev. 2004;84(3):935-86.

2. Ho MH, Bhatia NN, Khorram 0. Physiologic role of nitric oxide and nitric oxide synthase in female lower urinary tract. Curr Opin Obstet Gynecol. 2004;16(5):423-9.

3. Fathian-Sabet B, Bloch W, Klotz T, Niggemann S, Jacobs G, Addicks K, et al. Localization of constitutive nitric oxide synthase isoforms and the nitric oxide target enzyme soluble guanylyl cyclase in the human bladder. J Urol. 2001;165(5):1724-9.

4. Bennett BC, Kruse MN, Roppolo JR, Flood HD, Fraser M, de Groat WC. Neural control of urethral outlet activity in vivo: role of nitric oxide. J Urol. 1995; 153(6):2004-9.

5. Persson K, Igawa Y, Mattiasson A, Andersson KE. Effects of inhibition of the L-arginine/nitric oxide pathway in the rat lower urinary tract in vivo and in vitro. Br J Pharmacol. 1992;107(1):178-84.

6. Masuda H, Okuno T, Suzuki M, Kihara K, Goto M, Azuma H. Different distribution of nitric oxide synthase and soluble guanylyl cyclase activities in the detrusor and proximal urethra of the rabbit. J Urol. 2002;168(5):2286-90.

7. Burnett AL, Calvin DC, Chamness SL, Liu JX, Nelson RJ, Klein SL et al. Urinary bladder-urethral sphincter dysfunction in mice with targeted disruption of neuronal nitric oxide synthase models idiopathic voiding disorders in humans. Nat Med. 1997;3(5):571-4.

8. Persson K, Pandita RK, Aszòdi A, Ahmad M, Pfeifer A, Fässler R, et al. Functional characteristics of urinary tract smooth muscles in mice lacking cGMP protein kinase type I. Am J Physiol Regul Integr Comp Physiol. 2000;279(3):R1112-20.

9. Mónica FZ, Bricola AA, Báu FR, Freitas LL, Teixeira SA, Muscará MN, et al. Long-term nitric oxide deficiency causes muscarinic supersensitivity and reduces beta(3)-adrenoceptor-mediated relaxation, causing rat detrusor overactivity. Br J Pharmacol. 2008;153(8):1659-68.

10. Stasch JP, Becker EM, Alonso-Alija C, Apeler H, Dembowsky K, Feurer A, et al. NO-independent regulatory site on soluble guanylate cyclase. Nature. 2001;410(6825):212-5.

11. Baracat JS, Teixeira CE, Okuyama CE, Priviero FB, Faro R, Antunes $E$, et al. Relaxing effects induced by the soluble guanylyl cyclase stimulator BAY 41-2272 in human and rabbit corpus cavernosum. Eur J Pharmacol. 2003;477(2):163-9.

12. Priviero FB, Baracat JS, Teixeira CE, Claudino MA, De Nucci G, Antunes E. Mechanisms underlying relaxation of rabbit aorta by BAY 41-2272, a nitric oxide-independent soluble guanylate cyclase activator. Clin Exp Pharmacol Physiol. 2005;32(9):728-34.
13. Teixeira CE, Priviero FB, Todd J Jr, Webb RC. Vasorelaxing effect of BAY 412272 in rat basilar artery: involvement of cGMP-dependent and independent mechanisms. Hypertension. 2006;47(3):596-602.

14. Zanfolin M, Faro R, Araujo EG, Guaraldo AM, Antunes E, De Nucci G. Protective effects of BAY 41-2272 (sGC stimulator) on hypertension, heart, and cardiomyocyte hypertrophy induced by chronic L-NAME treatment in rats. J Cardiovasc Pharmacol. 2006;47(3):391-5.

15. Schroder A, Hedlund P, Andersson KE. Carbon monoxide relaxes the female pig urethra as effectively as nitric oxide in the presence of $\mathrm{YC}-1$. J Urol. 2002;167(4):1892-6.

16. Toque HA, Antunes E, Teixeira CE, De Nucci G. Increased cyclic guanosine monophosphate synthesis and calcium entry blockade account for the relaxant activity of the nitric oxide-independent soluble guanylyl cyclase stimulator BAY 41-2272 in the rabbit penile urethra. Urology. 2008;72(3):711-5.

17. Baú FR, Mónica FZ, Priviero FB, Baldissera L Jr, De Nucci G, Antunes E. Evaluation of the relaxant effect of the nitric oxide-independent soluble guanylyl cyclase stimulator BAY 41-2272 in isolated detrusor smooth muscle. Eur J Pharmacol. 2010;637(1-3):171-7.

18. Ribeiro MO, Antunes E, de Nucci G, Lovisolo SM, Zatz R. Chronic inhibition of nitric oxide synthesis. A new model of arterial hypertension. Hypertension. 1992;20(3):298-303.

19. Persson K, Alm P, Johansson K, Larsson B, Andersson KE. Nitric oxide synthase in pig lower urinary tract: immunohistochemistry, NADPH diaphorase histochemistry and functional effects. Br J Pharmacol. 1993;110(2):521-30.

20. Andersson KE, Persson K. Nitric oxide synthase and nitric oxide-mediated effects in lower urinary tract smooth muscles. World J Urol. 1994;12(5):274-80.

21. Gamé X, Allard J, Escourrou G, Gourdy P, Tack I, Rischmann P, et al. Estradiol increases urethral tone through the local inhibition of neuronal nitric oxide synthase expression. Am J Physiol Regul Integr Comp Physiol. 2008:294(3):R851-7.

22. Soler R, Füllhase C, Lu B, Bishop CE, Andersson KE. Bladder dysfunction in a new mutant mouse model with increased superoxide - lack of nitric oxide? J Urol. 2010;183(2):780-5.

23. Mamas AM, Reynard JM, Brading AF. Nitric oxide and the lower urinary tract: current concepts, future prospects. Urology. 2003;61(6):1079-85.

24. Sergeant GP, Hollywood MA, McHale NG, Thornbury KD. $\mathrm{Ca}^{2+}$ signalling in urethral interstitial cells of Cajal. J Physiol. 2006;576(Pt 3):715-20.

25. Artim DE, Kullmann FA, Daugherty SL, Wu HY, de Groat WC. Activation of the nitric oxide-cGMP pathway reduces phasic contractions in neonatal rat bladder strips via protein kinase G. Am J Physiol Renal Physiol. 2009;297(2):F333-40.

26. Reitz A, Knapp PA, Müntener M, Schurch B. Oral nitric oxide donors: a new pharmacological approach to detrusor-sphincter dyssynergia in spinal cord injured patients? Eur Urol. 2004;45(4):516-20.

27. Müntener M, Schurch B, Wefer B, Reitz A. Systemic nitric oxide augmentation leads to a rapid decrease of the bladder outlet resistance in healthy men. Eur Urol. 2006;50(1):112-7.

28. Osawa H, Chancellor MB, Jung SY, Yokoyama T, Fraser MO, Yu Y, et al. Effect of intravesical nitric oxide therapy on cyclophosphamide-induced cystitis. J Urol. 1999;162(6):2211-6. 